\title{
Effects of concentrated viral communities on photosynthesis and community composition of co- occurring benthic microalgae and phytoplankton
}

\author{
Ian Hewson ${ }^{1, *}$, Judith M. O'Neil ${ }^{2}$, Cynthia A. Heil ${ }^{3}$, Gunnar Bratbak ${ }^{4}$, \\ William C. Dennison ${ }^{1}$ \\ ${ }^{1}$ Marine Botany Group, Department of Botany, and ${ }^{2}$ Centre for Marine Studies, University of Queensland, Brisbane \\ Queensland 4072, Australia \\ ${ }^{3}$ College of Marine Science, University of South Florida, 140 7th Ave. S., St Petersburg, Florida 33701, USA \\ ${ }^{4}$ Department of Microbiology, University of Bergen, Jahnebakken 5, 5020 Bergen, Norway
}

\begin{abstract}
Marine viruses have been shown to affect phytoplankton productivity; however, there are no reports on the effect of viruses on benthic microalgae (microphytobenthos). Hence, this study investigated the effects of elevated concentrations of virus-like particles on the photosynthetic physiology and community composition of benthic microalgae and phytoplankton. Virus populations were collected near the sediment surface and concentrated by tangential flow ultrafiltration, and the concentrate was added to benthic and water column samples that were obtained along a eutrophication gradient in the Brisbane River/Moreton Bay estuary, Australia. Photosynthetic and community responses of benthic microalgae, phytoplankton and bacteria were monitored over $7 \mathrm{~d}$ in aquaria and in situ. Benthic microalgal communities responded to viral enrichment in both eutrophic and oligotrophic sediments. In eutrophic sediments, Euglenophytes (Euglena sp.) and bacteria decreased in abundance by 20 to 60 and 26 to $66 \%$, respectively, from seawater controls. In oligotrophic sediments, bacteria decreased in abundance by 30 to $42 \%$ from seawater controls but the dinoflagellate Gymnodinium sp. increased in abundance by 270 to $3600 \%$ from seawater controls. The increased abundance of Gymnodinium sp. may be related to increased availability of dissolved organic matter released from lysed bacteria. Increased (140 to $190 \%$ from seawater controls) initial chlorophyll a fluorescence measured with a pulse-amplitude modulated fluorometer was observed in eutrophic benthic microalgal incubations following virus enrichment, consistent with photosystem II damage. Virus enrichment in oligotrophic water significantly stimulated carbon fixation rates, perhaps due to increased nutrient availability by bacterial lysis. The interpretation of data from virus amendment experiments is difficult due to potential interaction with unidentified bioactive compounds within seawater concentrates. However, these results show that viruses are capable of influencing microbial dynamics in sediments.
\end{abstract}

KEY WORDS: Benthic microalgae $\cdot$ Moreton Bay · Virus-like particles $\cdot$ PAM fluorometry

\section{INTRODUCTION}

Viruses are ubiquitous in marine environments, with typical abundances of between $10^{5}$ and $10^{7}$ virus-like

*Present address: Department of Biological Sciences, University of Southern California, 3616 Trousdale Parkway AHF 107, Los Angeles, California 90089-0371, USA. E-mail: hewson@usc.edu particles (VLP) $\mathrm{ml}^{-1}$ (Fuhrman 1999, Wilhelm \& Suttle 1999, Wommack \& Colwell 2000). Viral infection affects both photosynthesis and biomass in phytoplankton (Suttle et al. 1990, Suttle 1992, Milligan \& Cosper 1994, Nagasaki et al. 1999) as well as in bacterioplankton biomass (Proctor \& Fuhrman 1992, Mathias et al. 1995, Middelboe et al. 1996). Viruses have also been implicated in the decline of phytoplankton blooms (Bratbak et al. 1990, 1993) and viruses may be 
a source of nutrition for heterotrophic nanoflagellates (Gonzales \& Suttle 1993). The abundance of benthic viruses has been shown to exceed the abundance of water column viruses by 10 to 1000 times (Paul et al. 1993, Maranger \& Bird 1996, Steward et al. 1996, Drake et al. 1998, Danovaro \& Serresi 2000). Given the elevated microalgal and bacterial biomass in sediments compared with the overlying water column (de Jonge \& Colijn 1994), viruses have the potential to play a significant role in benthic microbial communities.

Bacteria have been reported to be the most abundant organisms in sediments (Canon et al. 1998). Benthic microalgae (microphytobenthos) also have substantial biomass and abundance in marine sediments, particularly in shallow oligotrophic areas such as coral reefs (Heil et al. unpubl. data, Light \& Beardall 1998). Benthic microalgae are diverse assemblages of both autotrophs and heterotrophs (MacIntyre et al. 1996) that play significant roles in the ecology of Australian estuaries. They contribute substantially to primary production and hence oxygenation of sediments, and they are an abundant food source for invertebrates and fish (Kendrick et al. 1996, 1998, Light \& Beardall 1998). In Australian subtropical estuaries benthic microalgal biomass ranges from 20 to $200 \mathrm{mg}$ chlorophyll a (chl a) $\mathrm{m}^{-2}$ (Kendrick et al. 1996, 1998, Light \& Beardall 1998) and frequently exceeds the phytoplankton biomass in overlying waters ( 1 to $10 \mathrm{mg} \mathrm{chl} \mathrm{a} \mathrm{m}^{-2}$ ) as well as photosynthetic rates of other component flora in some areas (Dennison \& Abal 1999).

Virus infection may be a common cause of mortality in both benthic microalgae and phytoplankton. To date, mortality of benthic microalgae has been attributed to grazing, burial, resource exhaustion or apoptosis (Fenchel \& Staarup 1971). The mechanisms by which viral infection result in mortality to microalgae

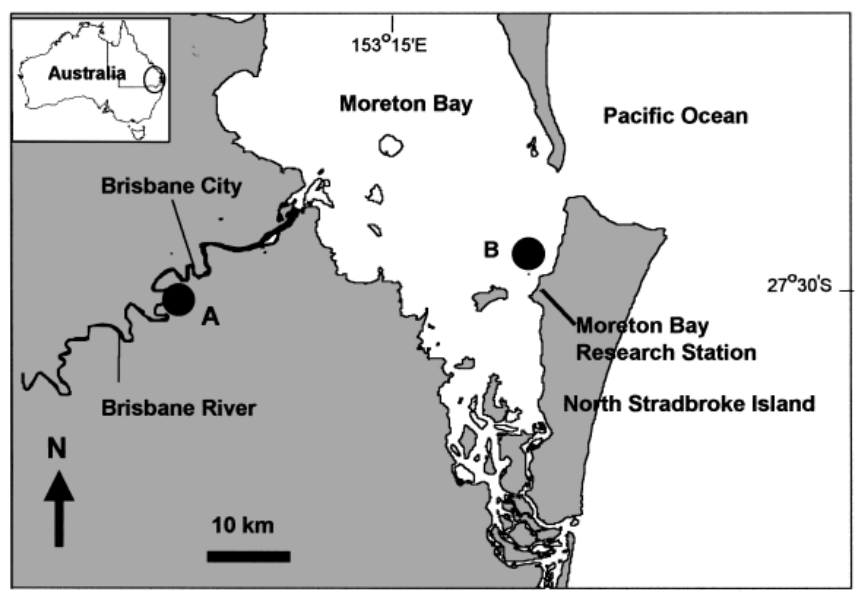

Fig. 1. Location of (A) oligotrophic and (B) eutrophic experimental stations in Moreton Bay, Queensland, Australia are not well understood, nor is the magnitude of mortality due to viral infection known. Cultures of microalgae, including the benthic pennate diatom Navicula sp. (common in estuarine sediments [Underwood et al. 1998]), exhibited a 99\% reduction in biomass with additions of high molecular weight concentrates (HMWCs) from oligotrophic seawater compared with controls with no additions (Suttle et al. 1990). Phytoplankton photosynthesis can be inhibited by up to $78 \%$ with the addition of HMWCs that are rich in viruses with capsids larger than $30 \mathrm{~nm}$ (Suttle 1992). In addition, viral infection of bacteria and cyanobacteria may be an important loss mechanism in sediments (Proctor \& Fuhrman 1990), since it has been estimated that 6 to $52 \%$ of particle-associated pelagic bacterial mortality is caused by viruses (Proctor et al. 1993).

The aims of this study were to examine the effects of elevated virus abundances on (1) the photosynthetic physiology and (2) the community structure of benthic microalgae from both eutrophic and oligotrophic areas of the Brisbane River/Moreton Bay Estuary, Queensland, Australia. In addition, the effects of elevated virus abundances on the photosynthetic capacity of overlying phytoplankton communities from both areas were determined.

\section{METHODS}

Study sites. Moreton Bay is a large $\left(\sim 700 \mathrm{~km}^{2}\right) \mathrm{sub}-$ tropical $\left(27^{\circ} \mathrm{S}, 153^{\circ} \mathrm{E}\right)$ semi-enclosed embayment located in southeastern Queensland (Fig. 1). The bay is relatively shallow (average depth $8 \mathrm{~m}$ ) and characterized by large east-west gradients in trophic status and suspended solid concentrations that persist throughout the year (Abal \& Dennison 1996, Heil et al. 1998, O'Donohue et al. 1998). The 2 sediment types examined in this study were from the Brisbane River and from eastern Moreton Bay, which are at the extremes of this trophic gradient. The Brisbane River site is considered eutrophic (Dennison \& Abal 1999) and is characterized by relatively long residence time ( $>150 \mathrm{~d}$ ), an average salinity of $25 \%$, tidal flushing ( $2 \mathrm{~m}$ tidal range) and finegrained muds (Dennison \& Abal 1999). The benthic microalgal community present within $2 \mathrm{~mm}$ of the sediment surface was dominated by Euglena spp. and pennate diatoms (Hewson et al. in press). In contrast the oligotrophic station (salinity 35.5\%) was located on an intertidal sand flat west of North Stradbroke Island in an area subject to continuous oceanic flushing (residence time $<7 \mathrm{~d}$ ). Benthic microalgal communities at this site were also dominated by pennate diatoms, although dinoflagellates (Prorocentrum spp., Gymnodinium spp.) were 
present in much smaller proportions $(\sim 2.4 \%$ of total community). Although benthic microalgal biomass was highest in the top $2 \mathrm{~cm}$ of sediment, the distribution of benthic microalgal cells suggests that these microalgae are present to depths of $>10 \mathrm{~cm}$ (Hewson et al. in press). Experiments were located in the intertidal zone at both stations and were submerged for approximately $20 \mathrm{~h}$ each day.

The effects of viral amendment were determined using both in situ and aquaria experiments for sediments and aquaria experiments for phytoplankton (Fig. 2). Viral effects on benthic microalgae were determined by enriching sediment porewaters with viruses concentrated from seawater collected above the sediment surface. Effects of concentrated viruses on phytoplankton were determined by enriching seawater with viruses concentrated from the same station.

Benthic microalgae experiments. In situ incubations: Nine PVC collars (diameter $110 \mathrm{~mm}$, height $100 \mathrm{~mm}$ ) were pushed into the sediment to $\sim 90 \mathrm{~mm}$ depth and enclosed at the top with a polyethylene light-transparent cover (500 ml Nasco Whirlpak [Nasco, Kansas City, KS, USA] bags) secured with a rubber band. Whirlpaks were pre-soaked for $6 \mathrm{~h}$ in $0.2 \mathrm{~N} \mathrm{HCl}$ to remove UV-released toxins (HolmHansen \& Helbling 1993). The cover was $\sim 5 \mathrm{~mm}$ above the sediment surface and enclosed $\sim 50 \mathrm{ml}$ of water. Covers prevented the loss of resuspended sediment upon initial manipulation.

Aquaria experiments: Sediment cores $(110 \mathrm{~mm}$ diameter, $60 \mathrm{~mm}$ depth) from the 2 sites were taken using a pipe corer, immediately placed into $250 \mathrm{ml}$ polystyrene vials and transported intact to glass tanks containing 301 seawater collected from the site. Cores were enclosed with polyethylene covers (pre-soaked in $0.5 \mathrm{~N} \mathrm{HCl}$ for $6 \mathrm{~h}_{\text {; }}$ head of water $\sim 50 \mathrm{ml}$ ). Tanks containing the cores were continuously aerated and incubated outdoors in aquaria in which water flow-through was used to maintain constant temperature $\left(18^{\circ} \mathrm{C}\right)$.

Preparation of HMWCs: A single HMWC was prepared for each study site by collecting 301 surface seawater in black polyethylene carboys (pre-soaked in $0.5 \mathrm{~N} \mathrm{HCl}$ ). Seawater was transported to the laboratory at ambient temperature and HMWCs were processed within $1 \mathrm{~h}$ of sample collection in the following manner.

All potential hosts were removed by gently $(250 \mathrm{~mm}$ $\mathrm{Hg}$ ) filtering $5 \mathrm{l}$ of seawater from each station through $0.8 \mathrm{~mm}$ Whatman GF/F (Whatman, Maidstone, UK), followed by filtration through a $0.22 \mu \mathrm{m}$ Durapore filter (Millipore Corporation, Bedford, MA, USA). The resulting filtrate was then concentrated by tangential flow ultrafiltration using a peristaltic-pump driven

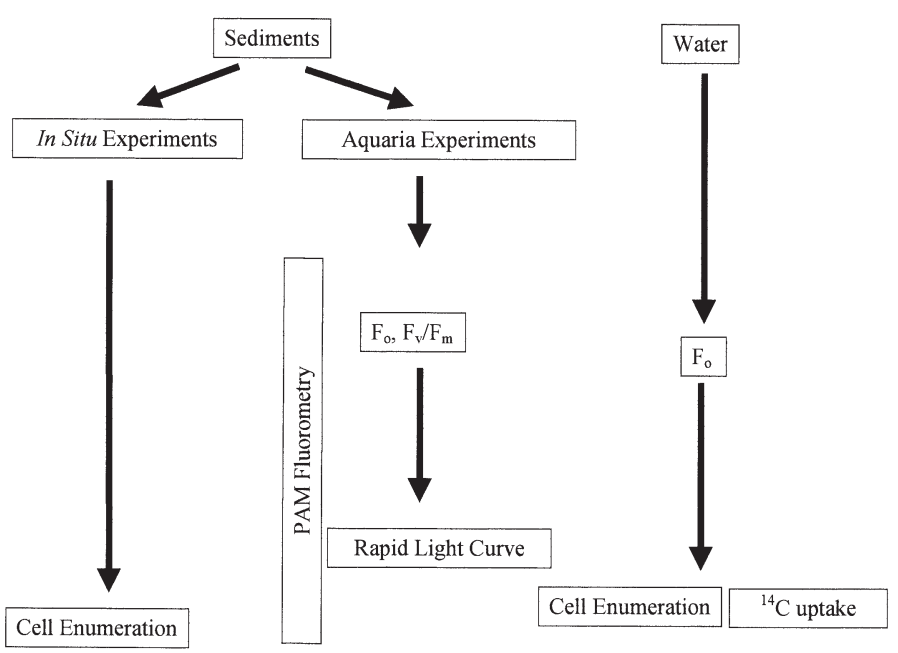

Fig. 2. Protocol for determining the effects of viruses on benthic microalgae and phytoplankton. $F_{\mathrm{m}}$ : maximum excitable fluorescence; $F_{0}$ : initial fluorescence; $F_{\mathrm{v}}: F_{\mathrm{m}}-F_{0}$; PAM: pulse-amplitude modulated fluorometry

Vivaflow (Vivascience, Hannover, Germany) 200 unit (molecular weight cut off $>30000 \mathrm{Da}$ ) to $50 \mathrm{ml}$. One half of the concentrated volume was heat treated in a microwave $\left(5 \mathrm{~min}\right.$ at $>100^{\circ} \mathrm{C}$ ), transferred to an open glass container and exposed for $5 \mathrm{~min}$ to UV light using an UV lamp (Oliphant UV Products, Arndell Park, NSW, Australia; $\lambda \approx 250$ to 350 ). This treatment is assumed to have denatured capsid proteins or destroyed virus infectivity and served as the heat-treated control in all experiments. It is worth noting, however, that previous studies have shown that viruses are still capable of infecting cells after UV sterilisation (Weinbauer et al. 1997, 1999, Wilhelm et al. 1998). Both heattreated concentrate and HMWCs were used immediately after preparation.

For both in situ and aquaria experiments, the HMWC fraction was injected (8 $\mathrm{ml}$ into each core) through the polyethylene covers, into the sediment surface to a depth of approximately $2 \mathrm{~mm}$ through a sterile syringe and steel needle at approximately 30 points within each core. After $24 \mathrm{~h}$ the polyethylene cover was removed and the cores were then subjected to ambient conditions. Seawater from the site and the heat-treated concentrate fraction were also added to 3 replicate cores each to serve as controls. Cores were incubated for $7 \mathrm{~d}$ and each core was sampled at random positions at 0 and $7 \mathrm{~d}$ for enumeration of microorganisms.

The abundance of viruses in concentrates was determined by epifluorescence microscopy after staining small (100 $\mu$ l) subsamples of seawater concentrate with SYBR Green I (Molecular Probes, Inc.) (Noble \& Fuhrman 1998), while the abundance of benthic 
viruses at both stations was determined using SYBR Green I staining of eluted sediment samples (Noble \& Fuhrman 1998, Hewson et al. in press). Briefly, small cores (5 ml syringe, $2 \mathrm{~cm}$ depth) of sediment from the experiment location were eluted in $35 \mathrm{ml} 0.02 \mu \mathrm{m}$ filtered phosphate-buffered saline $(120 \mathrm{mM} \mathrm{NaCl}$, $10 \mathrm{mM} \mathrm{NaH}_{2} \mathrm{PO}_{4}, \mathrm{pH}$ 7) and agitated for $60 \mathrm{~min}$ on a shaker table. The samples were then allowed to settle for approximately $20 \mathrm{~min}$, after which the phosphatebuffered saline was removed. Small aliquots of this phosphate-buffered saline were then filtered onto $0.02 \mu \mathrm{m}$ Whatman Anodisc filters, dried on the surface of tissue paper, then stained with 1:100000 diluted SYBR Green I. After 15 min staining, filters were dried once more and placed on a glass slide, and small drops of mountant ( $50 \%$ glycerol, $50 \%$ phosphate-buffered saline and $0.1 \%$ p-phenylenediamine) were added.

Pulse-amplitude modulated fluorometry: Photosynthetic parameters (maximum photosynthetic rate, photochemical efficiency, quenching) and fluorescence of sediment surface microalgae in cores in aquaria were measured using a pulse-amplitude modulated (PAM) diving fluorometer (Walz Mess- and Regeltechnik, Bremen, Germany) (Hartig et al. 1998, White \& Critchley 1999). Cores were placed in darkness for 15 min before all measurements to dark adapt the samples. The optic fiber cable, which delivers light emitted from a diode at $650 \mathrm{~nm}$ from the fluorometer to the sample and vice versa, was placed through a black polycarbonate ring ( $3 \mathrm{~cm}$ diameter) so that the end of the cable was flush with the ring surface. Measurements were taken by placing the polycarbonate ring/optical fiber cable assembly gently onto the sediment surface at random positions in each core. Initial fluorescence $\left(F_{0}\right)$ and photochemical efficiency $\left(F_{\mathrm{v}} / F_{\mathrm{m}}\right.$, where $F_{\mathrm{m}}$ is the maximum excitable fluorescence and $F_{\mathrm{v}}$ is $\left.F_{\mathrm{m}}-F_{0}\right)$, were measured and instantaneous light (photosynthesis-irradiance) curves were generated at ambient light ( $300 \mu \mathrm{mol}$ quanta $\left.\mathrm{m}^{-2} \mathrm{~s}^{-2}\right)$ using stepwise increasing saturating light pulses from 0 to $2000 \mu \mathrm{E} \mathrm{m}^{-2} \mathrm{~s}^{-1}$ over $90 \mathrm{~s}$. Three replicate measurements of fluorescence and photosynthesis were generated in each core at 1, 3 and $7 \mathrm{~d}$ after HMWC addition.

Microorganism enumeration: Benthic microalgae subcores ( $2 \mathrm{~cm}$ depth, diameter $13 \mathrm{~mm}$ ) were removed from each core after $7 \mathrm{~d}$ using a $60 \mathrm{ml}$ cut-off syringe and fixed immediately in $3.5 \%$ formalin. Subcores were resuspended in $0.22 \mu \mathrm{m}$ filtered seawater by agitation for 30 min on a shaker table and aliquots of supernatant were placed in a Palmer-Molloney counting chamber and enumerated. It is assumed that the agitation removed all benthic microalgae from sediment particles. More than 200 cells (total) of microalgae were counted in each sample in volumes of $0.1 \mathrm{ml} \mathrm{su}-$ pernatant examined by bright-field microscopy at 100 to $400 \times$ magnification. Bacteria were enumerated by collecting sediment subcores $(2 \mathrm{~cm}$ depth, diameter 13 $\mathrm{mm}$ ) with a syringe-corer from each core after $7 \mathrm{~d}$. Sediment was then eluted in $35 \mathrm{ml} 0.22 \mu \mathrm{m}$ filtered phosphate-buffered saline by agitation on a shaker table. Small volumes $(0.5 \mathrm{ml})$ of eluted samples were then stained with acridine orange and filtered through 0.22 $\mu \mathrm{m}$ irgalan black-stained polycarbonate filters (Osmonics, Minnetonka, MN, USA) followed by repeated rinsing with $0.22 \mu \mathrm{m}$ filtered seawater to remove excess stain. Bacteria were enumerated with epifluorescence microscopy under blue light excitation at 100x magnification (Parsons et al. 1985).

Phytoplankton experiments. Seawater from both oligotrophic and eutrophic sites was collected in $30 \mathrm{l}$ black polyethylene carboys (pre-soaked in $0.5 \mathrm{~N} \mathrm{HCl}$ ) and transported to the laboratory at ambient temperature $\left(18^{\circ} \mathrm{C}\right)$. Seawater was then placed into $4 \mathrm{l}$ polyethylene carboys (pre-soaked in $0.5 \mathrm{~N} \mathrm{HCl}$ ) and floated in a large outdoor aquarium under ambient light and constant temperature $\left(18^{\circ} \mathrm{C}\right)$. HMWCs and heat-treated concentrates were prepared as described above in seawater collected from each site. Approximately $5000 \mathrm{ml}$ was concentrated to a final volume of $50 \mathrm{ml}$, and half of this was treated with UV light and microwaving as described previously. After preparation of concentrates, subsamples $(50 \mathrm{ml})$ of seawater were placed in $60 \mathrm{ml}$ polypropylene centrifuge tubes and inoculated with $~ 8 \mathrm{ml} \mathrm{HMWC}$, heat-treated concentrate or seawater. Centrifuge tubes were then floated in the outdoor aquaria. In vivo fluorescence of phytoplankton in each tube was determined at $0,1,3$ and $7 \mathrm{~d}$ after inoculation. Well-mixed subsamples $(5 \mathrm{ml})$ from each centrifuge tube were dark adapted for $30 \mathrm{~min}$, then measured using a TD-700 fluorometer (Turner Designs, Sunnyvale, CA, USA) after dark adaptation for $30 \mathrm{~min}$.

${ }^{14} \mathrm{C}$-bicarbonate incorporation: At the conclusion of the $7 \mathrm{~d}$ incubation, phytoplankton productivity was measured in duplicate for each treatment by ${ }^{14} \mathrm{C}$-bicarbonate incorporation (Parsons et al. 1985 using modifications of O'Donohue \& Dennison 1997). Briefly, duplicate $50 \mathrm{ml}$ samples of seawater were placed in polypropylene centrifuge tubes to which $4 \mu \mathrm{Ci}^{14} \mathrm{CO}_{3}{ }^{2-}$ was added. Tubes were incubated for $2 \mathrm{~h}$ at ambient light intensity $\left(\sim 200 \mu \mathrm{mol}\right.$ quanta $\left.\mathrm{m}^{-2} \mathrm{~s}^{-1}\right)$ with 1 dark replicate from each station used as a control. Following incubation, samples were filtered through $0.45 \mu \mathrm{m}$ polycarbonate filters (Osmonics) and rinsed twice with $1 \mathrm{~N} \mathrm{HCl}$ to remove unincorporated radioactive carbon. Filters were then placed in $4 \mathrm{ml}$ scintillation fluid (Beckman Ready Scint, Beckman-Coulter, Fullerton, CA, USA). Disintegrations min $^{-1}$ were measured using a Packard 1600TR (Packard Instrument Company, Berks, UK) scintillation counter and these were converted to carbon fixation rate (Parsons et al. 1985). Two 
replicate measurements of each treatment were made and the third replicate was used for microorganism enumeration.

Microorganism enumeration: Phytoplankton samples $(50 \mathrm{ml})$ were preserved at the conclusion of the experiment in $3.5 \%$ formalin and allowed to settle for $24 \mathrm{~h}$ in $50 \mathrm{ml}$ centrifuge tubes. After $24 \mathrm{~h}$ the supernatant was removed to a final volume of $5 \mathrm{ml}$. Phytoplankton were enumerated by bright field microscopy at 100 to $400 \times$ total magnification in a Sedgwick-Rafter slide. More than 200 cells (total) of microalgae were counted in each sample in $1 \mathrm{ml}$ concentrate. Microalgae were identified to species level where possible according to Tomas (1997).

Bacteria were enumerated by collecting small samples of seawater $(6 \mathrm{ml})$ from each phytoplankton experiment centrifuge tube at the conclusion of the experiment that were fixed immediately in $3.5 \%$ formalin. Samples were then stained with acridine orange and enumerated using epifluoresence microscopy as described previously.

Statistical analyses. Triplicate samples of independent parameters (e.g., virus abundance, bacterial abundance) were analyzed by 1-way ANOVA using the statistical software package in Microsoft Excel 98 (Microsoft Corporation, Redmond, WA, USA). This included analysis of photosynthetic parameters $\left(F_{0}\right.$, $\left.F_{\mathrm{v}} / F_{\mathrm{m}}\right)$ in independent sediment cores at different sampling times in HMWC addition experiments.

\section{RESULTS}

\section{Virus enrichment effects on benthic microalgae}

Direct SYBR Green I counts showed an absence of bacteria in HMWC and final virus abundance in concentrates was approximately $6.3 \times 10^{10} \mathrm{VLP} \mathrm{ml}^{-1}$ from the oligotrophic site and $6.2 \times 10^{12} \mathrm{VLP} \mathrm{ml}^{-1}$ from the eutrophic site. Ambient concentrations of viruses in sediments at the eutrophic site were $2.2 \times 10^{11} \mathrm{VLP}$ $\mathrm{cm}^{-3}$ and at the oligotrophic site approximately $2.4 \times$ $10^{8} \mathrm{VLP} \mathrm{cm}^{-3}$, while water column abundances at the eutrophic site were $2.4 \times 10^{9} \mathrm{VLP} \mathrm{ml}^{-1}$ and at the oligotrophic site $2.3 \times 10^{8} \mathrm{VLP} \mathrm{ml}^{-1}$. The addition of HMWC is estimated to have elevated benthic virus abundance in the top $2 \mathrm{~mm}$ of sediment in cores by approximately $130 \%$ in eutrophic cores and $1200 \%$ in oligotrophic cores assuming even distribution of HMWC throughout sediment porewater.

Treatments with additions of seawater, heat-treated concentrate and HMWC caused substantial resuspension of fine-grained substrates in eutrophic sediments, which reduced photosynthesis to undetectable levels in the first $24 \mathrm{~h}$ of the experiment. Oligotrophic sediments did not show this negative effect, probably due to the relatively fast settling time of large-grained sands. Therefore, data are not reported for the first $24 \mathrm{~h}$ of the experiment at either station due to potential effects of sediment resuspension on microalgal hosts.
Fig. 3. Effects of high molecular weight concentrate (HMWC) on photosynthesis $( \pm \mathrm{SE})$ in benthic microalgae of oligotrophic (right) and eutrophic (left) sediments over time and range of different incident irradiences. Error bars indicate SE

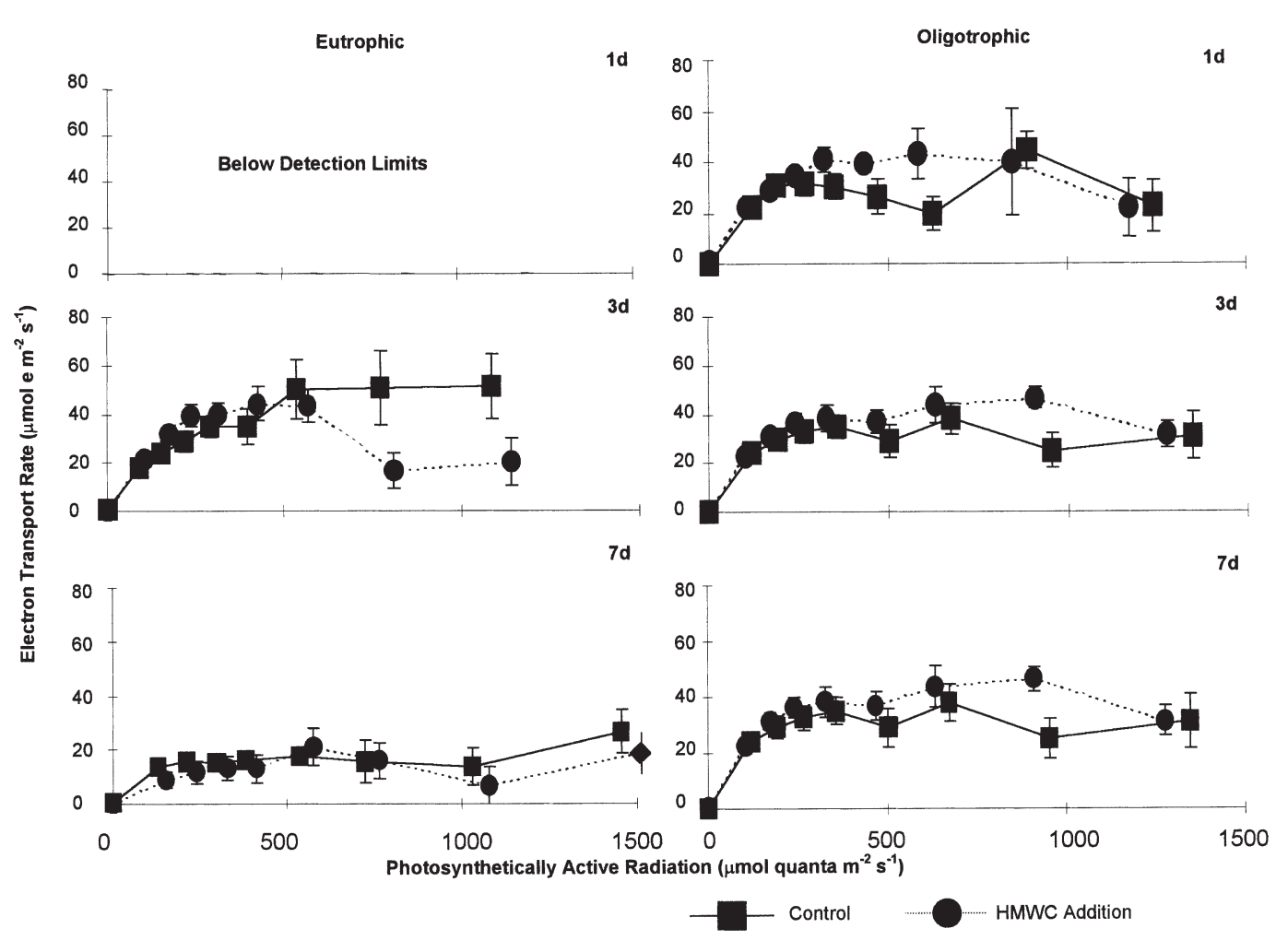


Table 1. Benthic and pelagic microbial community responses to high molecular weight concentrate (HMWC) additions after $7 \mathrm{~d}$ in March 2000. Mean $\pm \mathrm{SE}_{;} \mathrm{n}=3$ replicates treatment ${ }^{-1}$. HTC: heat-treated control; SC: seawater control; nd: no data due to bacterial aggregation; ${ }^{*} \mathrm{p}<0.05$

\begin{tabular}{|c|c|c|c|c|c|c|}
\hline Stn & Treatment & $\begin{array}{l}\text { Heterotrophic bacteria } \\
\qquad\left(\times 10^{6} \text { cells } \mathrm{cm}^{-3}\right)\end{array}$ & $\begin{array}{l}\text { a Total diatoms } \\
\left(\times 10^{3} \text { cells } \mathrm{cm}^{-3}\right)\end{array}$ & $\begin{array}{c}\text { Euglena sp. } \\
\left(\times 10^{3} \text { cells } \mathrm{cm}^{-3}\right)\end{array}$ & $\begin{array}{l}\text { Gymnodinium sp. } \\
\left(\times 10^{3} \text { cells cm } \mathrm{cm}^{-3}\right)\end{array}$ & $\begin{array}{l}\text { Carbon fixation rate } \\
\qquad\left(\mathrm{mg} \mathrm{C} \mathrm{m}^{-3} \mathrm{~h}^{-1}\right)\end{array}$ \\
\hline \multicolumn{7}{|c|}{ Benthic incubactions } \\
\hline \multirow[t]{3}{*}{ Eutrophic } & $\mathrm{SC}$ & $2.6 \pm 0.3$ & $3.6 \pm 0.3$ & $2.5 \pm 1.0$ & - & - \\
\hline & HTC & $2.8 \pm 0.3$ & $6.2 \pm 0.6$ & $1.4 \pm 0.5$ & & - \\
\hline & HMWC & $1.5 \pm 0.2^{*}$ & $3.4 \pm 0.9$ & $1.1 \pm 0.1^{*}$ & & - \\
\hline \multirow[t]{3}{*}{ Oligotrophic } & $\mathrm{SC}$ & $3.9 \pm 0.2$ & $28.6 \pm 2.6$ & - & $0.8 \pm 0.3$ & - \\
\hline & HTC & $3.1 \pm 0.3$ & $23.8 \pm 3.3$ & - & $2.5 \pm 0.5^{*}$ & - \\
\hline & HMWC & $2.5 \pm 0.1^{*}$ & $28.5 \pm 2.7$ & - & $10.5 \pm 7.5^{*}$ & - \\
\hline \multicolumn{7}{|c|}{ Pelagic incubations } \\
\hline \multirow[t]{3}{*}{ Eutrophic } & $\mathrm{SC}$ & $5.3 \pm 0.5$ & $2.1 \pm 1.2$ & - & - & $0.02 \pm 0.00$ \\
\hline & HTC & nd & $2.7 \pm 0.8$ & - & - & $0.03 \pm 0.01$ \\
\hline & HMWC & nd & $1.1 \pm 0.5$ & - & - & $0.02 \pm 0.01$ \\
\hline \multirow[t]{3}{*}{ Oligotrophic } & $\mathrm{SC}$ & $1.1 \pm 0.1$ & $28.4 \pm 1.1$ & - & - & $1.63 \pm 0.24$ \\
\hline & HTC & nd & $26.0 \pm 0.8$ & - & - & $2.88 \pm 0.08^{*}$ \\
\hline & HMWC & nd & $39.1 \pm 0.6^{*}$ & - & - & $3.08 \pm 0.16^{*}$ \\
\hline
\end{tabular}

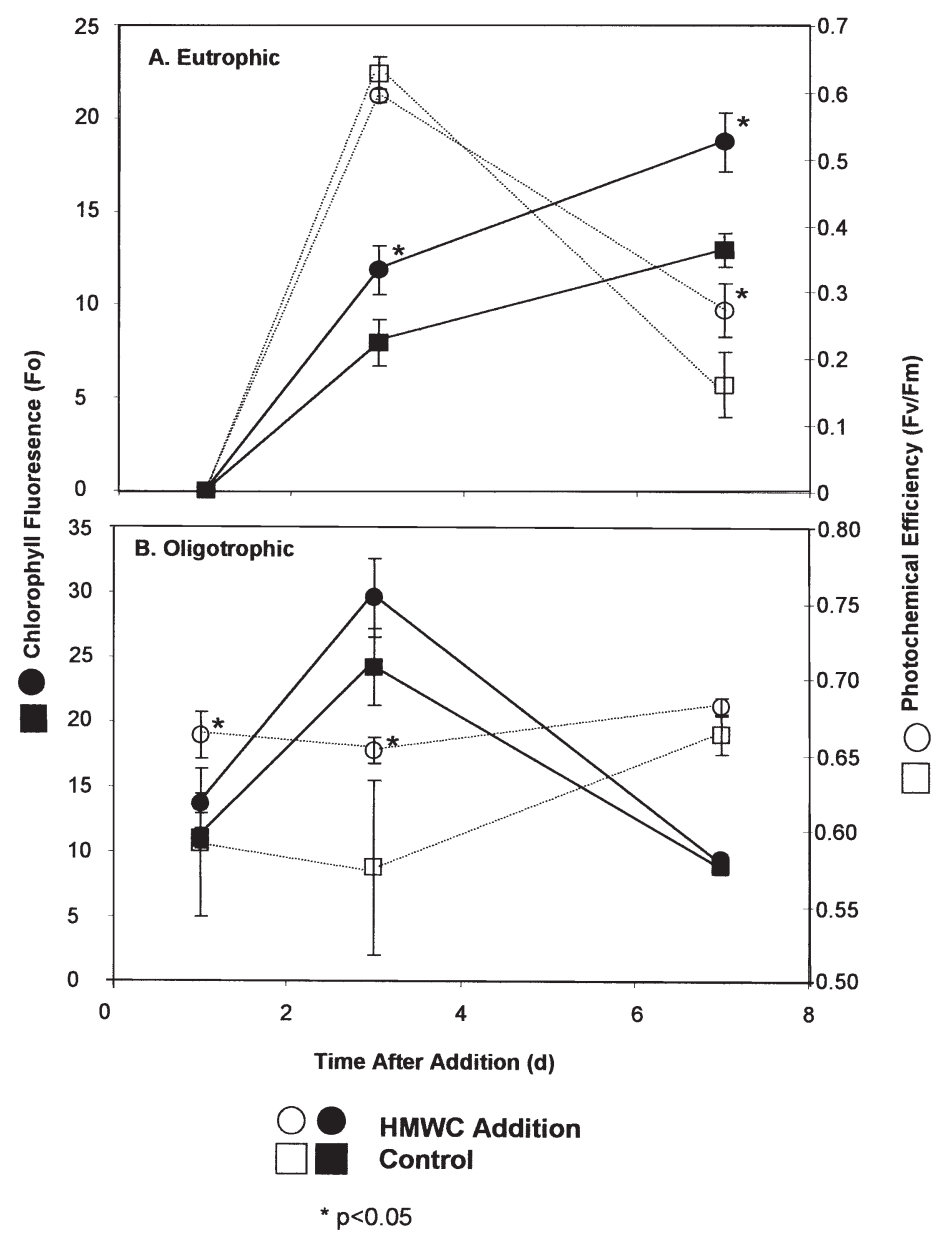

Fig. 4. Effects of HMWC addition $( \pm \mathrm{SE})$ on photosynthetic parameters of benthic microalgae in (A) eutrophic and (B) oligotrophic sediments over $7 \mathrm{~d}$
The time required for a significant change in photosynthesis within sediment incubations varied between oligotrophic and eutrophic sediments (Fig. 3). Heat-treated controls were not significantly different from seawater controls in terms of photosynthetic capacity $\left(F_{0}, F_{\mathrm{v}} / F_{\mathrm{m}}\right)$ and there was no visible difference in instantaneous light curves (data not shown for figure clarity). The effects of virus enrichment were observed within the first $3 \mathrm{~d}$ of the experiment in eutrophic sediments, while in oligotrophic sediments there was no evidence of virus infection on photosynthesis at $7 \mathrm{~d}$. Evidence of viral infection in eutrophic sediments included photoinhibition of electron transport rate at light intensities greater than $600 \mu \mathrm{mol}$ quanta $\mathrm{m}^{-2} \mathrm{~s}^{-1}$, a $26 \%$ decrease in Euglena sp. abundance compared with seawater controls (Table 1) and a significant increase $(\mathrm{p}<0.05)$ in $F_{0}$ (Fig. 4). No significant effect of HMWC addition on maximum electron transport rate or photochemical efficiency $\left(F_{\mathrm{v}} / F_{\mathrm{m}}\right)$ was observed.

Microbial cell abundance changed at both stations with the addition of HMWC (Table 1). The abundance of bacteria at both the oligotrophic and eutrophic stations significantly $(\mathrm{p}<0.05)$ decreased with virus enrichment. The abundance of the dinoflagellate Gymnodinium sp. increased significantly $(\mathrm{p}<0.05)$ at the oligotrophic station with HMWC and heat-treated concentrate additions. However, the abundance of bacteria did not change significantly in heat-treated concentrate additions. Virus enrichment significantly $(p<0.05)$ decreased the abundance of the green alga Euglena sp. in eutrophic sediments. The total abundance of diatoms did not change during the experiment at either station. 


\section{Virus enrichment effects on phytoplankton}

The addition of HMWC to seawater is estimated to have elevated virus abundance in treatments by $700 \%$ in eutrophic water and $106 \%$ in oligotrophic water above seawater controls. Additions of HMWC significantly ( $\mathrm{p}<0.05$ ) influenced phytoplankton communities at both the eutrophic and oligotrophic stations. Effects of heat-treated concentrates on $F_{0}$ were not significantly different from seawater controls at either station (data not shown). Increased in vivo chlorophyll fluorescence of phytoplankton was inhibited at the eutrophic station by $60 \%$ after $3 \mathrm{~d}$ compared with controls, while chlorophyll fluorescence at the oligotrophic station was significantly different from, and lower than controls after $1 \mathrm{~d}$, and then higher after $3 \mathrm{~d}$ (Fig. 5). After $7 \mathrm{~d}$, HMWC additions to water from the eutrophic and oligotrophic stations had no significant effects on fluorescence compared with controls. Although photosynthetic rates of phytoplankton from the oligotrophic site were significantly $(\mathrm{p}<0.05)$ elevated with HMWC and heat-treated concentrate additions (Table 1), the productivity of phytoplankton from the eutrophic site with HMWC additions was not significantly different from seawater controls after $7 \mathrm{~d}$ (Table 1). Additionally, the productivity of phytoplankton was substantially lower than productivity at the oligotrophic site despite higher biomass. This can be attributed to high turbidity within water samples as this area is the most turbid in the Brisbane River (Dennison \& Abal 1999).

Containment of phytoplankton communities from eutrophic and oligotrophic stations in both control and HMWC additions significantly $(\mathrm{p}<0.05)$ increased the abundance of the diatoms Skeletonema costatum, Melosira sulcata and Coscinodiscus argus, while in oligotrophic incubations, the abundance of Chaetoceros spp. was significantly $(\mathrm{p}<0.05)$ stimulated in all treatments (data not shown). Large bacterial aggregates formed at both stations with HMWC and heat-treated control addition and were not present in controls.

\section{DISCUSSION}

Changes in virus concentrations affected the abundance and photosynthetic physiology of both phytoplankton and benthic microalgae in Moreton Bay. Therefore, viruses potentially exert an important influence on the photosynthesis, biomass and community composition of microalgae and bacteria living in both the water column and on surficial sediments in Moreton Bay.

The observed decrease in bacterial abundance in both oligotrophic and eutrophic sediment incubations with HMWC addition suggests that some viruses in near-benthic seawater are bacteriophage specific to hosts on and within the sediments. This is consistent with previous reports that found that the majority of viruses in seawater are bacteriophages (reviewed recently in Fuhrman 1999, Wommack \& Colwell 2000).

Decrease in benthic microalgal photosynthesis in eutrophic sediments upon viral augmentation suggests that viral lysis of algae in these environments may be an important cause of benthic microalgal mortality. The stimulation of dinoflagellate populations in oligotrophic sediments by HMWC and heat-treated concentrate addition suggests that virally mediated lysis products (of bacteria and microalgae) may be an important source of nutrients for uninfected and resistant auto- and heterotrophs in oligotrophic sediments (Gonzales \& Suttle 1993).

Dinoflagellates can grow well on large dissolved organic molecules, and are capable of utilizing dissolved organic nitrogen (Heil et al. 2001, Carlsson et al. 1998, Doblin et al. 1999, Glibert \& Terlizzi 1999). The increased abundance of the dinoflagellate Gymnodinium sp. with HMWC addition may be due to its ability to utilize dissolved organic material from bacterial lysis products (Middelboe et al. 1996) or uptake of dissociated genetic material and proteins in heat-treated concentrate additions. Dinoflagellates may also phagocytize virus particles as a source of organic material. VLP have been observed previously in vacuoles of heterotrophic pelagic dinoflagellates (Hallegraeff \& Lucas 1988). It is also conceivable that the removal of bacteria

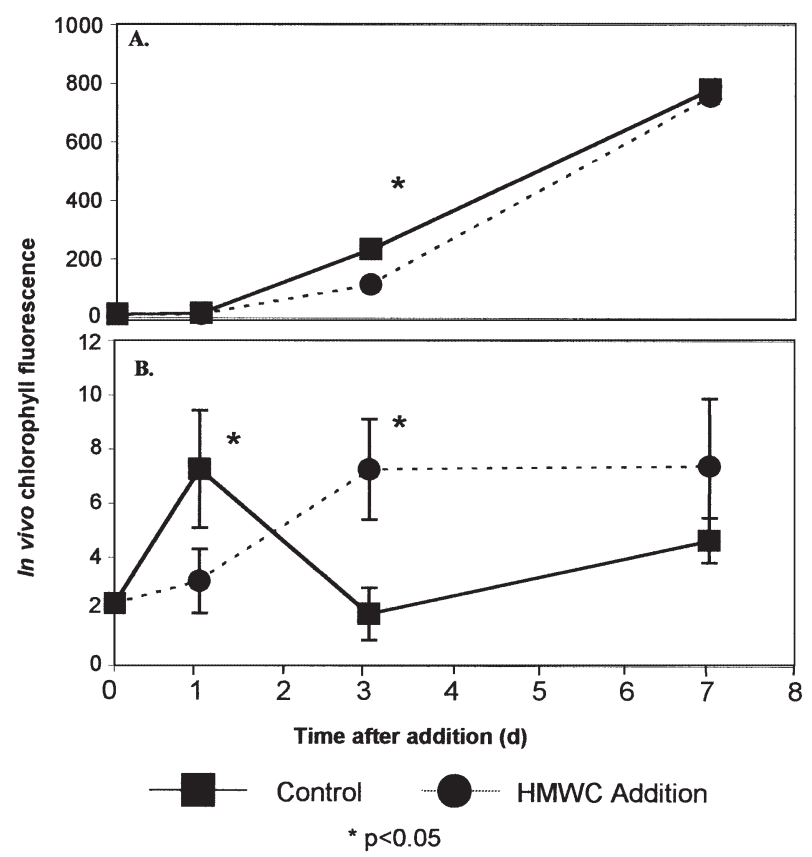

Fig. 5. Effect of HMWC addition to (A) eutrophic and (B) oligotrophic phytoplankton in vivo chlorophyll fluorescence 
may stimulate dinoflagellate abundance since they potentially compete for organic nutrients (Carlsson et al. 1998). HMWCs also contain bioactive macromolecules (e.g., extracellular DNA) that may have stimualted dinoflagellate growth; however, this is unlikely since a previous study has shown that HMWC augmentation of seawater does not cause significant enrichment of dissolved organic matter (Weinbauer \& Peduzzi 1995).

There are several reasons why Euglena sp. may be more susceptible to HMWC additions than other benthic microalgae. Viruses internalized within Euglena sp. have been previously observed (Woongghi \& Sung Min 1999), and viruses of several related species of green algae including Platymonas sp. and Pyramimonas orientalis have been observed within cells (Moestrup \& Thomsen 1974, Pearson \& Norris 1974). Euglena sp. does not have thecal plates or thick cell walls, and therefore may be less mechanically resistant to infection as co-occurring diatoms. HMWC additions did not significantly change the abundance of benthic microalgae at the oligotrophic site, which was dominated by diatoms and thecate dinoflagellates. Benthic microalgae from the oligotrophic site may therefore be more mechanically resistant to potential infection than eutrophic assemblages.

The increased in vivo fluorescence of phytoplankton from the oligotrophic station with HMWC addition, concomitant with an increased abundance of diatoms after $7 \mathrm{~d}$, may be due to uptake of lysis products (of both microalgae and bacteria) by resistant phytoplankton, as has been observed in previous studies (Table 2; Suttle 1992). The inhibition of in vivo fluorescence increase in phytoplankton from the eutrophic station (also corresponding to a decrease in diatom abundance after 7 d) indicates phytoplankton mortality, which may be due to viral lysis (Suttle et al. 1991). Aggregation of bacteria at both stations with HMWC addition has been observed previously (Peduzzi \& Weinbauer 1993) and may be due to growth of uninfected bacteria on lysis products of infected bacteria. The results suggest tightly coupled nutrient cycling in the water column of both the oligotrophic and eutrophic sites, which may be induced by viral mortality of phytoplankton and bacteria.

There is no direct evidence from the present study that microalgal nutrition plays a role in susceptibility to virus infection. The community composition of microalgae was completely different at the 2 stations assayed; hence, any effects of varying nutritional status of hosts between the 2 sites were masked by differences in community composition. Despite this, in low nutrient environments lysogeny (or latent infection) in microalgae may be more common than lytic infection; hence, addition of lytic viruses would have comparatively little effect on the abundance of microalgae (Jiang \& Paul 1997). This is consistent with the observed lack of change in hosts other than bacteria in oligotrophic environments. In addition, the turnover time of organisms in oligotrophic waters is slower than in eutrophic waters; for example, doubling times of bacteria in oligotrophic sediments in summer are typically 4 to $16 \mathrm{~d}$ (Moriarty et al. 1985). Hence, the latent period (i.e., the time between infection and lysis) of both bacteria and microalgae may help explain the lack of infection observed in oligotrophic waters in comparison with eutrophic waters after $7 \mathrm{~d}$.

The results suggest that lytic viruses play a role in the microbial ecology of oligotrophic sediments and overlying waters; however, the effects of virus augmentation were observed primarily in sediments. The greater abundance of most microorganisms in coastal sediments than in the water column in oligotrophic areas (Paul et al. 1993, Heil unpubl. data) may simply make changes to microalgal photosynthesis and community composition upon viral amendment more evident. In eutrophic waters, by contrast, the roles played by viruses in microbial ecology are evident in both the water column and benthos, potentially due to the large abundance of bacteria and microalgae in both environments. The observed roles of viruses in oligotrophic and eutrophic areas may also reflect the ambient abundance of benthic viruses in these areas. For exam-

Table 2. Reported changes in biomass and photosynthesis of mixed phytoplankton communities with viral concentrate addition. Chl a: chlorophyll $a_{i}$ (1) Present study; (2) Peduzzi \& Weinbauer (1993); (3) Suttle (1992); (4) Weinbauer \& Peduzzi (1995)

\begin{tabular}{|lccccccc|}
\hline Location & $\begin{array}{c}\text { Max. decrease } \\
\text { in biomass } \\
(\%)\end{array}$ & $\begin{array}{c}\text { Max. increase } \\
\text { in biomass } \\
(\%)\end{array}$ & $\begin{array}{c}\text { Time of } \\
\text { decrease } \\
(\mathrm{h})\end{array}$ & $\begin{array}{c}\text { Time of } \\
\text { increase } \\
(\mathrm{h})\end{array}$ & $\begin{array}{l}\text { Method } \\
\text { used }\end{array}$ & $\begin{array}{c}\text { Decrease in } \\
\text { photosynthesis } \\
(\%)\end{array}$ \\
\hline Moreton Bay benthic microalgae & -26 & 32 & 168 & 168 & Cell counts & 0 & $(1)$ \\
Moreton Bay phytoplankton & -47 & 38 & 168 & 168 & Cell counts & -6 to -89 & $(1)$ \\
Aurisina, Adriatic Sea & -90 & 60 & 125 & 125 & Chl a (extracted) & nd & $(2)$ \\
Port Aransas, Gulf of Mexico & -39 & 627 & 23 & 145 & Chl a (in vivo) & -10 to -60 & $(3)$ \\
Aurisina, Adriatic Sea & - & 28 & - & 210 & Chl a (extracted) & nd & $(4)$ \\
Northern Adriatic Sea & - & 67 & - & 225 & Chl a (extracted) & nd \\
\end{tabular}


ple, studies of marine virus abundance in oligotrophic sediments found between 100 and 1000 more VLP than in overlying waters (Paul et al. 1993, Hewson et al. in press), while in eutrophic areas, this difference is closer to 10 to 100 (Drake et al. 1998).

PAM fluorometry has not been previously used in the study of viral infection in photosynthetic marine organisms, and has only recently been applied to sediments to determine benthic microalgal photosynthetis (Hartig et al. 1998, Heil et al. 2001). PAM fluorometry was used in this study primarily because it is nondestructive to the target microorganisms; hence, repeated measurement of the sediment surface is possible. This study shows that PAM fluorometry is a useful tool in the assessment of viral infection, as it allows simultaneous measurement of both photosynthetic capacity $\left(F_{0}\right.$ and $\left.F_{\mathrm{v}} / F_{\mathrm{m}}\right)$ and photosynthetic rate through generation of rapid photosynthesis-irradiance curves (White \& Chritchley 1999). The PAM fluorometer only measures sediment-surface microalgal chlorophyll fluoresence. However, previous studies have found chl $a$ at depths well below the sediment surface (de Jonge \& Colijn 1994), which may undergo daily vertical migrations to photosynthesize (Fenchel \& Staarup 1971). The use of the PAM fluorometer may therefore underestimate the effects of viral augmentation on benthic microalgal photosynthesis.

This study emphasizes the importance of the role of viruses in estuarine benthic microbial ecology and raises more questions about the role of benthic viruses in other marine environments, including the potential role viruses may play in providing nutrition for benthic dinoflagellates. Marine viruses appear to be active members of both benthic and pelagic microbial communities in eutrophic and oligotrophic regions and, as such, their ecological and biogeochemical roles in sediments and interactions with overlying waters warrant further study. This study also shows the usefulness of PAM fluorometry in assessing the effects of virus infection of benthic microalgae. This method of nondestructive photosynthesis measurement may prove useful in the future study of viral effects on other organisms, for example, corals, macroalgae and seagrass.

Acknowledgements. We are grateful to S. Albert, C. Miller, A.Watkinson and the Marine Botany Group for field assistance; J. Fuhrman and N. Mann for input in planning this study; J. Van Etten and C. Suttle for invaluable comments on interpreting these results; J. Fuhrman for supplying the Vivaflow unit; and P. Countway, M.S. Schwalbach and 4 anonymous reviewers for valuable comments that have substantially improved this work. This work was completed in partial fulfillment of a PG B.Sc (Hons) by I.H. and was supported by the Department of Botany at the University of Queensland and ARC grant \#C19937055 awarded to W.C.D.

\section{LITERATURE CITED}

Abal EG, Dennison WC (1996) Seagrass depth range and water quality in southern Moreton Bay, Queensland, Australia. Mar Freshw Res 47:763-771

Bratbak G, Heldal M, Norland S, Thingstad TF (1990) Viruses as partners in spring bloom microbial trophodynamics. Appl Environ Microbiol 56:1400-1405

Bratbak G, Egge JK, Heldal M (1993) Viral mortality of the marine alga Emiliania huxleyi (Haptophyceae) and termination of algal blooms. Mar Ecol Prog Ser 93:39-48

Canon C, Frankignoulle M, Windeshausen F, Delille D (1998) Short-term variations of bacterial communities associated with a Mediterranean Posidonia oceanica seagrass bed. Vie Milieu 48:321-329

Carlsson P, Edling H, Bechemin C (1998) Interactions between a marine dinoflagellate (Alexandrium catenella) and a bacterial community utilising riverine humic substances. Aquat Microb Ecol 16:65-80

Danovaro R, Serresi M (2000) Viral density and virus-to-bacterium ratio in deep-sea sediments of the eastern Mediterranean. Appl Environ Microbiol 66:1857-1861

de Jonge VN, Colijn F (1994) Dynamics of microphytobenthos biomass in the Ems estuary. Mar Ecol Prog Ser 104: 185-196

Dennison WC, Abal EG (eds) (1999) Moreton Bay study: a scientific basis for the healthy waterways campaign. Healthy Waterways, Brisbane

Doblin MA, Blackburn SI, Hallegraeff GM (1999) Growth and biomass stimulation of the toxic dinoflagellate Gymnodinium catenatum (Graham) by dissolved organic substances. J Exp Mar Biol Ecol 236:33-47

Drake LA, Choi KH, Haskell AGE, Dobbs FC (1998) Vertical profiles of virus-like particles and bacteria in the water column and sediments of Chesapeake Bay, USA. Aquat Microb Ecol 16:17-25

Fenchel T, Staarup BJ (1971) Vertical distribution of photosynthetic pigments and the penetration of light in marine sediments. Oikos 22:172-182

Fuhrman JA (1999) Marine viruses and their biogeochemical and ecological effects. Nature 399:541-548

Glibert PM, Terlizzi DE (1999) Co-occurrence of elevated urea levels and dinoflagellate blooms in temperate estuarine aquaculture ponds. Appl Environ Microbiol 65: $5594-5596$

Gonzales JM, Suttle CA (1993) Grazing by marine nanoflagellates on viruses and virus-sized particles: ingestion and digestion. Mar Ecol Prog Ser 94:1-10

Hallegraeff GM, Lucas IAN (1988) The marine dinoflagellate genus Dinophysis: photosynthetic, neritic and non-photosynthetic oceanic species. Phycologia 27:25-42

Hartig P, Wolfstein K, Lippemeier S, Colijn F (1998) Photosynthetic activity of natural microphytobentos populations measured by fluorescence (PAM) and ${ }^{14} \mathrm{C}$-tracer methods: a comparison. Mar Ecol Prog Ser 166:53-62

Heil CA, O'Donohue MJ, Miller CA, Dennison WC (1998) Phytoplankton community response to a flood event. In: Tibbets IR, Hall NJ, Dennison WC (eds) Moreton Bay and Catchment. School of Marine Science, University of Queensland, Brisbane, p 569-584

Heil CA, Glibert PM, Al-Sarawi MA, Faraj M, Behbehani M, Husain M (2001) First record of a fish-killing Gymnodinium selliforme bloom in Kuwait Bay, Arabian Sea: chronology and potential causes. Mar Ecol Prog Ser 214:15-23

Hewson I, O'Neil JM, Fuhrman JA, Dennison WC (in press) Virus-like particle distribution and abundance in the sedi- 
ments and overlying waters of two subtropical estuaries. Limnol Oceanogr

Holm-Hansen O, Helbling EW (1993) Polyethylene bags and solar ultraviolet radiation. Science 259:534-535

Jiang SC, Paul JH (1997) Significance of lysogeny in the marine environment: studies with isolates and a model of lysogenic phage production. Microb Ecol 35:235-243

Kendrick GA, Jacoby CA, Heinemann D (1996) Benthic microalgae: comparisons of chlorophyll $a$ in mesocosms and field sites. In: Lindstrom SC, Chapman DJ (eds) Fifteenth International Seaweed Symposium. Kluwer, Amsterdam, p 283-289

Kendrick GA, Langtry S, Fitzpatrick J, Griffiths R, Jacoby CA (1998) Benthic microalgae and nutrient dynamics in wavedisturbed environments in Marmion Lagoon, Western Australia, compared with less disturbed mesocosms. J Exp Mar Biol Ecol 228:83-105

Light BR, Beardall J (1998) Distribution and spatial variation of benthic microalgal biomass in a temperate, shallowwater marine system. Aquat Bot 61:39-54

MacIntyre HL, Geider RJ, Miller DC (1996) Microphytobenthos: the ecological role of the secret garden of unvegetated, shallow-water marine habitat. I. Distribution, abundance and primary production. Estuaries 19:186-201

Maranger P, Bird DF (1996) High concentrations of viruses in the sediments of Lake Gilbert, Quebec. Microb Ecol 31: $141-151$

Mathias CB, Kirschner AKT, Velimirov B (1995) Seasonal variations of virus abundance and viral control of the bacterial production in a backwater system of the Danube River. Appl Environ Microbiol 61:3734-3740

Middelboe M, Jorgensen NOG, Kroer N (1996) Effects of viruses on nutrient turnover and growth efficiency of noninfected marine bacterioplankton. Appl Environ Microbiol 62:1991-1997

Milligan KLD, Cosper EM (1994) Isolation of virus capable of lysing the Brown Tide microalga, Aureococcus anophagefferens. Science 266:805-807

Moestrup O, Thomsen HA (1974) An ultrastructural satudy of the flagellate Pyramimonas orientalis with particular emphasis on Golgi apparatus activity and the flagellar apparatus. Protoplasma 81:247-269

Moriarty DJW, Pollard PC, Hunt WG, Moriarty CM, Wassenberg TJ (1985) Productivity of bacteria and microalgae and the effect of grazing by holothurians in sediments on a coral reef flat. Mar Biol 85:293-300

Nagasaki K, Tarutani K, Yamaguchi M (1999) Growth characteristics of Heterosigma akashiwo virus and its possible use as a microbiological agent for red tide control. Appl Environ Microbiol 65:898-902

Noble RT, Fuhrman JA (1998) Use of SYBR Green I for rapid epifluoresence counts of marine viruses and bacteria. Aquat Microb Ecol 14:113-118

O'Donohue MH, Dennison WC (1997) Phytoplankton productivity response to nutrient concentrations, light availability and temperature along an Australian estuarine gradient. Estuaries 20:521-533

O'Donohue MJ, Heil CA, Lowe S, Horrocks J, Abal EG, Costanzo S, Dennison WC (1998) Assessing the impact of a flood event on Moreton Bay using marine plants as bioindicators of water quality. In: Tibbets IR, Hall NJ, Dennison WC (eds) Moreton Bay and Catchment. School of Marine Science, University of Queensland, Brisbane, p 585-596

Parsons TR, Maita Y, Lalli CM (1985) A manual of chemical and biological methods for seawater analysis. Pergamon Press, Oxford, p 81

Paul JH, Rose JB, Jiang SC, Kellogg CA, Dickson L (1993) Distribution of viral abundance in the reef environment of Key Largo, Florida. Appl Environ Microbiol 59:718-724

Pearson BR, Norris RE (1974) Intranuclear virus-like particles in the marine alga Platymonas sp. (Chlorophyta, Prasinophyceae). Phycologia 13:5-9

Peduzzi P, Weinbauer MG (1993) Effect of concentrating the virus-rich $2-200 \mathrm{~nm}$ size fraction of seawater on the formation of algal flocs (marine snow). Limnol Oceanog 38: 1562-1565

Proctor LM, Fuhrman JA (1990) Viral mortality of marine bacteria and cyanobacteria. Nature 343:60-62

Proctor LM, Fuhrman JA (1992) Mortality of marine bacteria in response to enrichments of the virus size fraction from seawater. Mar Ecol Prog Ser 87:283-293

Proctor LM, Okubo A, Fuhrman JA (1993) Calibrating estimates of phage-induced mortality in marine bacteria: ultrastructural studies of marine bacteriophage development from one-step growth experiments. Microb Ecol 25: 161-182

Steward GF, Smith DC, Azam F (1996) Abundance and production of bacteria and viruses in the Bering and Chukchi Sea. Mar Ecol Prog Ser 131:287-300

Suttle CA (1992) Inhibition of photosynthesis in phytoplankton by the submicron size fraction concentrated from seawater. Mar Ecol Prog Ser 87:105-112

Suttle CA, Chan AM, Cottrell MT (1990) Infection of phytoplankton by viruses and reduction of primary productivity. Nature 347:467-469

Suttle CA, Chan AM, Cottrell MT (1991) Use of ultrafiltration to isolate viruses from seawater which are pathogens of marine phytoplankton. Appl Environ Microbiol 57:721-726

Tomas CR (1997) Identifying marine phytoplankton. Academic Press, San Diego

Underwood GJ, Phillips J, Saunders K (1998) Distribution of estuarine benthic diatom species along salinity and nutrient gradients. Eur J Phycol 33:173-183

Weinbauer MG, Peduzzi P (1995) Effect of virus-rich high molecular weight concentrates of seawater on the dynamics of dissolved amino acids and carbohydrates. Mar Ecol Prog Ser 127:245-253

Weinbauer MG, Wilhelm SW, Suttle CA, Garza DR (1997) Photoreactivation compensates for UV-damage and restores infectivity to natural marine viral communities. Appl Environ Microbiol 63:2200-2205

Weinbauer MG, Wilhelm SW, Suttle CA, Pledger RJ, Mitchell DL (1999) Sunlight-induced DNA damage and resistance in natural viral communities. Aquat Microb Ecol 17: $111-120$

White AJ, Critchley C (1999) Rapid light curves: a new fluorescence method to assess the state of the photosynthetic apparatus. Photosynthesis Res 59:63-72

Wilhelm SW, Suttle CA (1999) Viruses and nutrient cycles in the sea. Bioscience 49:781-788

Wilhelm SW, Weinbauer MG, Suttle CA, Pledger RJ, Mitchell DL (1998) Measurements of DNA damage and photoreactivation imply that most viruses in marine surface waters are infective. Aquat Microb Ecol 14:215-222

Wommack KE, Colwell RR (2000) Viroplankton: viruses in aquatic ecosystems. Microb Mol Biol Rev 64:69-114

Woongghi S, Sung-Min B (1999) Virus-like particles in both nucleus and cytoplasm of Euglena viridis (Euglenophyceae). Arch Hydrobiol Suppl 130:125-131

Submitted: December 18, 2000; Accepted: May 31, 2001

Proofs received from author(s): July 19, 2001 